ISSN: 1410-8917

Jurnal Kimia

-Sains \&

Aplikasi

e-ISSN: 2597-9914
Jurnal Kimia Sains dan Aplikasi Journal of Scientific and Applied Chemistry

Journal homepage: http://ejournal.undip.ac.id/index.php/ksa

\title{
Activation of Natural Zeolite and Its Application for Adsorbents in Domestic Wastewater Treatment in Tembalang District, Semarang City
}

\author{
Suhartana ${ }^{\mathrm{a}, *}$, Pardoyo $^{\mathrm{a}}$ \\ ${ }^{\text {a }}$ Chemistry Department, Faculty of Sciences and Mathematics, Diponegoro University, Semarang, Indonesia \\ * Corresponding author: suhartana@live.undip.ac.id \\ https://doi.org/10.14710/jksa.23.1.28-33
}

Article Info

Article history:

Received: $11^{\text {th }}$ July 2019 Revised: $23^{\text {rd }}$ January 2020

Accepted: $27^{\text {th }}$ January 2020

Online: $31^{\text {st }}$ January 2020

Keywords:

domestic wastewater; natural zeolite; activated natural zeolite; $\mathrm{COD}$; $\mathrm{pH}$; BOD; TSS

\begin{abstract}
Tembalang is one of the districts in the city of Semarang whose economic growth is rapid. There are 12 sub-districts in Tembalang district, one of which is the Tembalang sub-district, which is within the campus area of Diponegoro University. When compared with other sub-district in the Tembalang district, the Tembalang subdistrict community's need for clean water and domestic wastewater disposal is very high because of its dense population. Handling domestic wastewater is one of the environmental problems, which is interesting to study. Domestic wastewater, in addition to causing environmental pollution, can also cause discomfort and even health problems. One way to reduce the impact of domestic wastewater is to treat domestic wastewater before the environment is discharged. This study aims to describe the character of domestic wastewater in Tembalang sub-district, Tembalang district, Semarang city, and the use of activated zeolites and activated zeolites to reduce $\mathrm{COD}, \mathrm{pH}, \mathrm{BOD}$, and TSS in domestic wastewater. Also, to compare the parameters of wastewater with regulations in force (Minister of Environment and Forestry Regulation No: 68 of 2016). This research is expected to improve the quality of domestic wastewater by adsorption using natural zeolite and activated zeolite adsorbents. The results showed that the adsorption treatment with natural zeolites and activated zeolites significantly improved water quality. The results of adsorption by natural zeolites showed a decrease in COD of $21.8 \%$, a pH of $11.5 \%$, BOD of $9.2 \%$, and a TSS of $10.8 \%$. Whereas adsorption by $\mathrm{HCl}$-activated zeolite resulted in a decrease in COD of $78.9 \%$, pH of $16.2 \%$, BOD of $11.8 \%$ \& TSS of $74.4 \%$. While $\mathrm{H}_{2} \mathrm{SO}_{4-}$ activated natural zeolite reduced COD by $85.5 \%, \mathrm{pH} 17.9 \%$, BOD $12.6 \%$ and TSS $89.7 \%$.
\end{abstract}

\section{Introduction}

Management of water resources and the environment requires multidisciplinary science to understand groundwater-surface water (GW-SW) interactions. This interaction forms a close relationship between terrestrial ecosystems, aquatic ecosystems, and the integrity of water resources [1]. The amount of land that is fixed, and the population that is always increasing, causes the problem of clean water sources and wastewater to be interesting to study. The problem of clean water and domestic wastewater is very much felt in big cities in the world, including in Indonesia [2]. This is compounded by the presence of active chemicals that are used directly in the household (such as detergents, shampoo, toothpaste, cooking oil), which are directly discharged into sewers without being treated first. Then the carrying capacity of the environment is reduced due to increasing waste disposal [3]. Therefore, domestic wastewater and hospital wastewater treatment before disposal in the sewer is absolutely necessary, as was done in Doha, Qatar [4]. This is somewhat different from the habits of the people in Indonesia. Indonesian people generally do not treat their domestic wastewater but are directly discharged into the surrounding water gutters. 
Tembalang is one of the districts in the city of Semarang whose economic growth is rapid. There are 12 sub-districts in the Tembalang district, and the Tembalang sub-district is the location of the Diponegoro University campus, as shown in Figure 1. Thus, the need for clean water and disposal of domestic wastewater becomes quite complicated, so it is interesting to study. Domestic wastewater, in addition to causing environmental pollution, can cause discomfort and even health problems. One way to reduce the impact of domestic wastewater is to treat domestic wastewater before it is discharged into the environment.

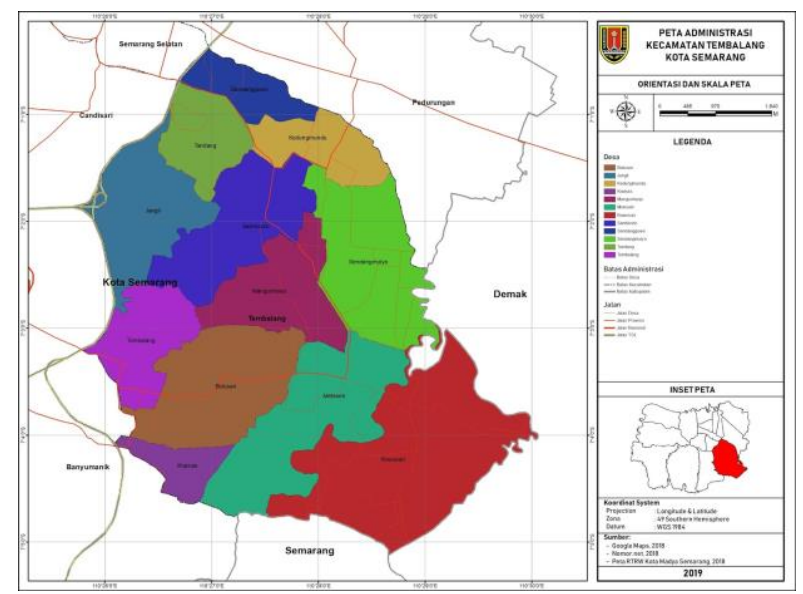

Figure 1. Map of Tembalang district

Previous studies of communal domestic wastewater treatment used a stratified screening process and water hyacinth bioremediation [5]. The results were quite satisfying but required a long time and a reasonably large area. Another way is to combine an Anaerobic Baffled Reactor (ABR), Anaerobic Filter (AF), and Upflow anaerobic sludge blanket (UASB). The combination of the three methods gave excellent results (removal above $80 \%$ ) but required a long time, expensive cost, and large area [6]. Another cheaper and easier way to do this was by adsorption using zeolites. The results were unsatisfactory if done only once (25\%), but if replicated up to 3 times, it obtained significant results $(74.5 \%)$. Whereas, if it was combined with iron sand and zeolite, it gave very satisfying results $(96.6 \%)$ [7].

The material for treating domestic wastewater by adsorption (with zeolite as an adsorbent) is still wide open. In Indonesia, zeolite deposits are very abundant [8]. Zeolite is a hydrated aluminosilicate crystal that has attractive properties and mesoporous structures. Some names of natural zeolites that are well known are mordenite, analcime, phillipsite, chabazite, heulandite, clinoptilolite, erionite, ferrierite, and laumontite [9]. Zeolites are usually used as adsorbents and catalysts in an industry or company. Natural zeolites, in general, have low thermal stability, non-uniform pore size, and low adsorption and catalytic activity. Therefore, it is necessary to modify zeolites to improve the adsorption and catalytic properties $[10,11]$.

Zeolite modifications made can be used by chemical modification methods such as dealumination with acids or cation exchange with metals. The addition of acid causes the aluminum to come out of the zeolite framework and increase the ratio of silica to alumina [10, $11,12,13,14]$. In this study, natural zeolites were used using $\mathrm{HCl}$ and $\mathrm{H}_{2} \mathrm{SO}_{4}$ to be further used to improve the quality of domestic wastewater in the Tembalang subdistrict, Tembalang district, through the adsorption process. Previously we had done zeolite dealumination for biodiesel synthesis purposes [15]. Measurement parameters observed were chemical oxygen demand (COD), pH, biological oxygen demand (BOD), and total suspended solids (TSS) in the domestic wastewater. Also, to compare the parameters of wastewater with applicable regulations (Minister of Environment and Forestry Regulation No: 68 of 2016). Samples of domestic wastewater were taken from 3 sub-districts, Kramas, Tembalang, and Meteseh. Natural zeolites and activated zeolites $\mathrm{HCl}$ and $\mathrm{H}_{2} \mathrm{SO}_{4}$ were characterized by FTIR spectroscopy, while the $\mathrm{Si} / \mathrm{Al}$ ratio was analyzed using Atomic Absorption Spectrophotometry (AAS).

\section{Methodology}

\subsection{Materials and Equipment}

The materials used were domestic wastewater (as much as 1 liter taken from three different sub-districts in Tembalang district as a sample), $250 \mathrm{~g}$ natural zeolite, hydrochloric acid ( $\mathrm{HCl}) 6 \mathrm{M}$, sulfuric acid $\left(\mathrm{H}_{2} \mathrm{SO}_{4}\right) 6 \mathrm{M}$, potassium permanganate $\left(\mathrm{KMnO}_{4}\right) 0.5 \mathrm{M}$, distilled water and silver nitrate $\left(\mathrm{AgNO}_{3}\right)$. While the equipment used was a pH meter, FTIR spectrometer, Atomic Absorption Spectrophotometry (AAS), 100-200 mesh sifter, some glassware, furnace, magnetic stirrer, water bath, a set of reflux apparatus, electric scales and hot plates.

\subsection{Sample Preparation}

Bayat natural zeolite was washed and soaked with distilled water overnight and dried at $110^{\circ} \mathrm{C}$ and then crushed until smooth and sieved with a size of 100-200 mesh.

\subsection{Dealumination of natural zeolites}

To $50 \mathrm{~g}$ of natural zeolite, $100 \mathrm{~mL} \mathrm{HCl} 6 \mathrm{M}$ and 100 $\mathrm{mL} \mathrm{KMnO}_{4} 0.5 \mathrm{M}$ were added. The mixture was heated at $80^{\circ} \mathrm{C}$ for 4 hours, then allowed to stand for one night $(48$ hours) at room temperature. The obtained mixture is then filtered and washed with distilled water until it was neutral (tested with $\mathrm{AgNO}_{3}$ solution until no white precipitate occurs) and dried at $110^{\circ} \mathrm{C}$ for 5 hours and calcined for 3 hours at $500^{\circ} \mathrm{C}$. The sample obtained was coded ZT1. The same thing was done using $\mathrm{H}_{2} \mathrm{SO}_{4}$ instead of $\mathrm{HCl}$, and the sample was given a ZT2 code.

\subsection{Characterization of natural zeolites, $\mathrm{HCl}$-activated zeolites, and $\mathrm{H}_{2} \mathrm{SO}_{4}$-activated zeolites \\ Characterization of $\mathrm{Si} / \mathrm{Al}$ ratio was performed on natural zeolites, $\mathrm{HCl}$ activated zeolites, and $\mathrm{H}_{2} \mathrm{SO}_{4}$ activated zeolites using Atomic Absorption Spectrophotometry (AAS). While the analysis of functional groups was carried out using Fourier- transform infrared spectroscopy (FTIR) spectrometers}




\subsection{Adsorption Performance Test}

\subsubsection{Collection and treatment of Domestic Waste Water Samples}

Before conducting the activity test, three subdistricts were taken in the Tembalang district, namely Kramas, Tembalang, and Meteseh. A total of $100 \mathrm{~mL}$ samples of domestic wastewater, $\mathrm{AgNO}_{3}$ added to remove chloride ions. A total of 1 gram of natural zeolite adsorbent was mixed into the sample and then heated at $40^{\circ} \mathrm{C}$ in a three-neck flask that was equipped with a thermometer and stirrer, then refluxed for 60 minutes. The same thing was done on zeolite, which was realized as $\mathrm{H}_{2} \mathrm{SO}_{4}$ and $\mathrm{HCl}$.

\subsubsection{Separation of Residues and Filtrates}

A mixture of adsorbed domestic wastewater, then filtered with filter paper to separate the filtrate and residue. The filtrate was wastewater that has been adsorbed while the residue is zeolite adsorbent. The filtrate was allowed to sit for a day and then for later analyzed.

\subsection{Analysis of waste that has been adsorbed}

Next, an analysis is performed on the sample solution, with Chemical oxygen demand (COD), $\mathrm{pH}$, biological oxygen demand (BOD) and Total suspended solids (TSS). Measuring for each process was carried out three times

\section{Results and Discussion}

Zeolites used are zeolites from the Klaten (Bayat) region. The clean and dry natural zeolite was crushed with porcelain mortal until smooth and sieved with a 100-200 mesh size sieve. Destruction was conducted to enlarge the surface area of natural zeolite so that the adsorption ability could be more optimal and could interact maximally with reactants. In zeolite that has been free of organic matter and impurities, a dealumination process was carried out by acidification with $\mathrm{H}_{2} \mathrm{SO}_{4}$ and $\mathrm{HCl}$ accompanied by the addition of $\mathrm{KMnO}_{4}$. The addition of $\mathrm{KMnO}_{4}$ was intended to oxidize existing organic impurities and metals. With the activation process carried out for 4 hours at $80^{\circ} \mathrm{C}$ and overnight at room temperature, it was expected that alumina coming out of the zeolite framework could be optimized. The addition of acid aimed to exchange cations to form zeolite- $\mathrm{H}$ where the cations in zeolite exchange with $\mathrm{H}^{+}$. Ion exchange between cations in zeolites with $\mathrm{H}^{+}$was intended to replace all the cations in zeolites because in zeolites; there are alkaline or alkaline earth cations such as $\mathrm{Na}^{+}, \mathrm{Ca}^{2+}, \mathrm{Mg}^{2+}$ which act as balancing charges [10, 11, 12].

As a result of acid addition, an interaction between the acid and zeolite results in the release of alumina species from the zeolite. $\mathrm{H}^{+}$ions derived from acids interact with free electrons in $\mathrm{O}$ atoms to form coordination bonds. Al-O groups will lack electrons so that they are more polar and weaker, so Al will break from the bonds $[10,11,12,13,14]$.

\subsection{FTIR analysis}

Figure 2 presents the FTIR spectrum of natural zeolites and zeolite dealumination using $\mathrm{HCl}$ and $\mathrm{H}_{2} \mathrm{SO}_{4}$, which displays characteristics of zeolite. The zeolite framework is shown in the range of wave numbers 300$1300 \mathrm{~cm}^{-1}$ originating from $\mathrm{O}-\mathrm{Si}-\mathrm{O}$ and $\mathrm{O}-\mathrm{Al}-\mathrm{O}$ tetrahedral bonds. The band $900-1250 \mathrm{~cm}^{-1}$ is an asymmetrical range, while the symmetrical range is shown in the band $650-850 \mathrm{~cm}^{-1}$, the bending of $\mathrm{Si}-$ $\mathrm{O} / \mathrm{Al}-\mathrm{O}$ (TO) internally appears in the region of 420-500 $\mathrm{cm}^{-1}$ while for the external it appears at $700-780 \mathrm{~cm}^{-1}[7$, $9,10,11,12,13,14,16]$.

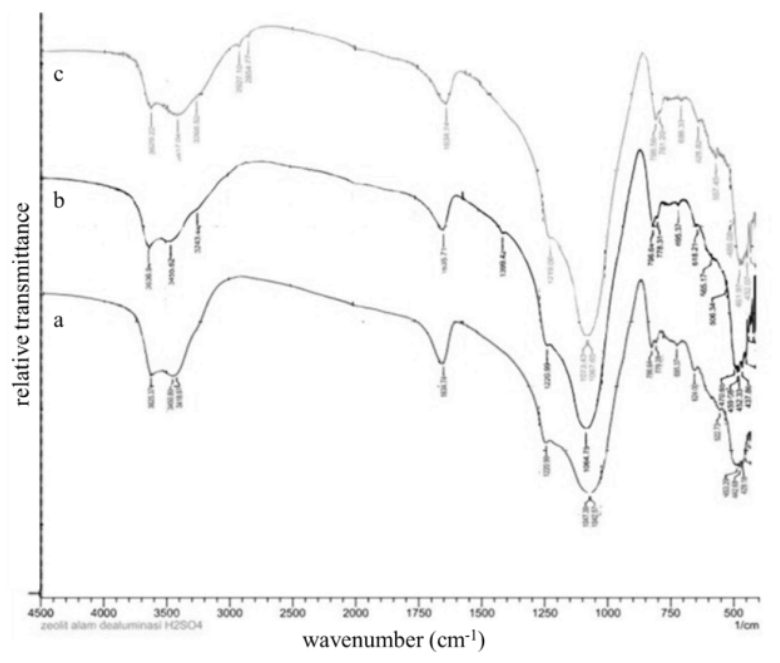

Figure 2. FTIR spectrum of (a) $\mathrm{H}_{2} \mathrm{SO}_{4}$-activated zeolite,

(b) $\mathrm{HCl}$ - activated zeolite, and (c) natural zeolite

Interpretation of the IR spectrum can be obtained from several absorption bands. Dealumination occurs when internal stretching vibrations ascend, and external stretching vibrations decrease in wavenumbers. The shift in the region $420-300 \mathrm{~cm}^{-1}$ in the direction of the lower wavenumber indicates the pore opening. Natural zeolite shows a peak at wave number $322.13 \mathrm{~cm}^{-1}$, natural $\mathrm{H}_{2} \mathrm{SO}_{4}$-activated zeolite is $313.45 \mathrm{~cm}^{-1}$, and that of $\mathrm{HCl}$ is $316.34 \mathrm{~cm}^{-1}$. This indicates that the pore opening occurs due to the dealumination process $[7,9,10,11,12]$. These results also show that dealumination with $\mathrm{H}_{2} \mathrm{SO}_{4}$ gives a greater pore opening than $\mathrm{HCl}$. It was further explained that internal vibrations related to $\mathrm{TO}_{4}(\mathrm{~T}=\mathrm{Si}, \mathrm{Al})$ tetrahedral, which is the main structural unit in the region of $950-1250 \mathrm{~cm}^{-1}$. These wavenumbers represent the internal interwoven of tetrahedral asymmetrical stretching vibration and the external interwoven of asymmetric stretching vibration. Absorption in this area shows a shift in the wavenumber, in which natural zeolite by $1042.57 \mathrm{~cm}^{-1}$, to $1072.47 \mathrm{~cm}^{-1}$ on $\mathrm{H}_{2} \mathrm{SO}_{4}-$ activated zeolite and $1064.75 \mathrm{~cm}^{-1}$ on $\mathrm{HCl}$-activated zeolite. A greater shift occurred in zeolite activated $\mathrm{H}_{2} \mathrm{SO}_{4}$ compare to $\mathrm{HCl}$. This shows that $\mathrm{H}_{2} \mathrm{SO}_{4}$ dealumination is more effective compared to $\mathrm{HCl}$.

This shift is due to the dealumination of natural zeolites so that the tetrahedral stretching vibration of the $\mathrm{T}-\mathrm{O}$ bend $(\mathrm{T}=\mathrm{Si}, \mathrm{Al})$ is more common in $\mathrm{Si}-\mathrm{O}$ bonds than $\mathrm{Al}-\mathrm{O}$. At wave numbers between $3400-3500 \mathrm{~cm}^{-1}$, peaks show the presence of water (hydrates) or free $\mathrm{OH}$ 
groups possessed by zeolite crystals $[7,9,10,11,12]$. The peak occurred at wavenumbers $3450.80 \mathrm{~cm}^{-1}$ for natural zeolites, $3417.04 \mathrm{~cm}^{-1}$ for $\mathrm{H}_{2} \mathrm{SO}_{4}$-activated zeolites, and $3455.62 \mathrm{~cm}^{-1}$ for $\mathrm{HCl}$-activated zeolites.

\subsection{Si/Al ratio analysis}

Table 1 presents the Si/Al ratio of natural zeolite, activated zeolite $\mathrm{H}_{2} \mathrm{SO}_{4}$, and $\mathrm{HCl}$.

Table 1. Si/Al Ratio of natural zeolite and activated zeolite

\begin{tabular}{ccc}
\hline No & Sample & Si/Al ratio \\
\hline 1 & Natural zeolite & 4.5662 \\
2 & $\mathrm{HCl}$-activated zeolites & 5.4098 \\
3 & $\mathrm{H}_{2} \mathrm{SO}_{4}$-activated zeolites & 6.4159 \\
\hline
\end{tabular}

Natural zeolite, which has not been dealuminated, has the lowest $\mathrm{Si} / \mathrm{Al}$ ratio of 4.5662 . While the ratio of $\mathrm{Si} / \mathrm{Al}$ to zeolite activated $\mathrm{H}_{2} \mathrm{SO}_{4}$ was the highest at 6.4159, compared to $\mathrm{HCl}$ of 5.4098 . This indicates that $\mathrm{H}_{2} \mathrm{SO}_{4}$ does dealumination more effectively than $\mathrm{HCl}$. These results have been similar to the study of Sriatun and Darmawan [17], where dealumination with $\mathrm{H}_{2} \mathrm{SO}_{4}$ was more effective compared to $\mathrm{HCl}$.

\subsection{Wastewater adsorption test}

Tests of the activity of adsorption of domestic wastewater by natural zeolites and acid-activated zeolites were carried out by mixing $100 \mathrm{~mL}$ of $100 \mathrm{~mL}$ domestic wastewater samples with $1 \mathrm{~g}$ of zeolite. This process was carried out at $40^{\circ} \mathrm{C}$ in a three-neck flask equipped with a thermometer and stirrer. It is expected that the intensity of the collision between the adsorbent and the adsorbate reaches its optimum point.
The results of the measurement of domestic wastewater from the three sub-districts located in Tembalang District (Kramas sub-district, Tembalang sub-district, and Meteseh sub-district) and the effectiveness of adsorption performance of natural zeolites (ZA), $\mathrm{HCl}$-activated zeolites (ZT 1 ) and $\mathrm{H}_{2} \mathrm{SO}_{4}-$ activated zeolite (ZT 2) can be seen in table 2 . The results of the analysis of domestic wastewater are compared with the Standard Quality Standards (Minister of Environment and Forestry Regulation No: 68 of 2016).

Table 2 shows that in Tembalang Sub-district, the $\mathrm{pH}, \mathrm{COD}, \mathrm{BOD}$, and TSS values are relatively higher when compared to the other two sub-districts (Kramas and Meteseh). This can be understood because the population density in Tembalang Sub-district is indeed higher. The presence of Diponegoro University students, Semarang State Polytechnic, Dental Care Academy, Pandanaran University, and the presence of food and beverage stalls adjacent to the college campuses affect the population density in the Tembalang Sub-district. With a dense population, it is inevitable that wastewater from washing and bathroom waste is also increasing.

The degree of acidity $(\mathrm{pH})$ represents the acidic or basic state of a solution. If the $\mathrm{pH}$ of the solution $<7$ means acid, whereas if the $\mathrm{pH}$ of the solution $>7$ means that the solution is basic $[1,3,18]$. The $\mathrm{pH}$ values in the three sub-districts (Tembalang, Kramas, and Meteseh) still meet the standards of the Quality Standards (Minister of Environment and Forestry Regulation No: 68 of 2016). However, the $\mathrm{pH}$ of domestic wastewater in Tembalang Sub-district is relatively higher. This might be due to the presence of a bath and washing wastewater, which is not processed and discharged directly into the environment.

Table 2. The results of the analysis of domestic wastewater in the Sub-district Kramas, Tembalang, and Meteseh and the effectiveness of the adsorption performance of natural zeolite (ZA), $\mathrm{HCl}$-activated zeolite ( $\mathrm{ZT} 1$ ) and $\mathrm{H}_{2} \mathrm{SO}_{4^{-}}$ activated zeolite (ZT 2)

\begin{tabular}{|c|c|c|c|c|c|c|c|c|c|c|c|c|c|c|}
\hline \multirow{3}{*}{ Parameter } & \multirow{3}{*}{ Method } & \multirow{3}{*}{$\begin{array}{c}\text { Quality } \\
\text { Standards }\end{array}$} & \multicolumn{4}{|c|}{ Kramas } & \multicolumn{4}{|c|}{ Tembalang } & \multicolumn{4}{|c|}{ Meteseh } \\
\hline & & & \multirow{2}{*}{ Results } & \multicolumn{3}{|c|}{$\begin{array}{c}\text { Adsorption } \\
\text { Effectiveness }\end{array}$} & \multirow{2}{*}{ Results } & \multicolumn{3}{|c|}{$\begin{array}{c}\text { Adsorption } \\
\text { Effectiveness }\end{array}$} & \multicolumn{4}{|c|}{ Adsorption Effectiveness } \\
\hline & & & & $\mathrm{ZA}$ & $\mathrm{ZT} 1$ & ZT 2 & & $\mathrm{ZA}$ & $\mathrm{ZT} 1$ & ZT 2 & ZA & $\mathrm{ZT} 1$ & $\mathrm{ZT} 2$ & $\mathrm{ZA}$ \\
\hline $\mathrm{pH}$ & $\begin{array}{c}\text { SNI } \\
06.6989 .11 .2004\end{array}$ & $6-9$ & 7.4 & $11.5 \%$ & $16.2 \%$ & $17.9 \%$ & 7.5 & $11.5 \%$ & $16.2 \%$ & $17.9 \%$ & 7.3 & $11.5 \%$ & $16.2 \%$ & $17.9 \%$ \\
\hline $\begin{array}{l}\text { Temperature } \\
\left({ }^{\circ} \mathrm{C}\right)\end{array}$ & $\begin{array}{c}\text { SNI } \\
06.6989 .23 .2005\end{array}$ & - & 27.3 & - & - & - & 27.3 & - & - & - & 27.3 & - & - & - \\
\hline $\mathrm{COD}(\mathrm{mg} / \mathrm{L})$ & SNI 6989.2.2009 & 50 & 70.6 & $21.8 \%$ & $78.9 \%$ & $85.5 \%$ & 86.7 & $21.8 \%$ & $78.9 \%$ & $85.5 \%$ & 71.2 & $26.4 \%$ & $78.9 \%$ & $85.5 \%$ \\
\hline BOD (mg/L) & $\begin{array}{c}\text { SNI } \\
06.6989 .72 .2009\end{array}$ & 100 & 47.8 & $9.2 \%$ & $11.8 \%$ & $12.6 \%$ & 59.6 & $9.2 \%$ & $11.8 \%$ & $12.6 \%$ & 49.1 & $9.2 \%$ & $11.8 \%$ & $12.6 \%$ \\
\hline TSS (mg/L) & $\begin{array}{c}\text { SNI } \\
06.6989 .10 .2004\end{array}$ & 30 & 38.8 & $10.8 \%$ & $44.4 \%$ & $49.7 \%$ & 56.8 & $10.8 \%$ & $44.4 \%$ & $49.7 \%$ & 46.6 & $11.7 \%$ & $44.4 \%$ & $49.7 \%$ \\
\hline
\end{tabular}

Chemical Oxygen Demand (COD) is the amount of oxygen needed by material to neutralize organic compounds dissolved in water. The measurement result of Chemical Oxygen Demand (COD) for the Tembalang sub-district is $86.7 \mathrm{ppm}$, higher than the Kramas subdistrict of $70.6 \mathrm{ppm}$, and the Meteseh sub-district of 71.2 ppm. This is due to the higher population density in Tembalang Sub-district so that the discharge of wastewater from the MCK and several food/beverage stalls is also higher. The higher the COD price in water indicates, the worse the quality of the water. Usually, excessive organic matter content in water, resulting in turbidity, odor, and color of the solution is no longer clear if the value of COD in water exceeds the specified threshold value. This can result in the destruction of ecosystems in the waters; even if this is not addressed 
correctly, it can damage the aquatic environment. To avoid this kind of thing, it is necessary to treat domestic wastewater before being discharged into sewers, so as not to pollute the environment $[19,20]$.

Biological Oxygen Demand (BOD) is the amount of oxygen needed by microorganisms to neutralize organic compounds dissolved in water. The measurement result of Biological Oxygen Demand in Tembalang Sub-district (BOD) is 59.6 (mg/L) which is higher than Kramas Subdistrict of $47.8 \mathrm{mg} / \mathrm{L}$ and Meteseh Sub-district of 49.1 $\mathrm{mg} / \mathrm{L}$. The higher the BOD value in a solution, the worse the quality of the water. Usually, excessive organic matter content in water, resulting in turbidity, odor, and color of the solution is no longer clear [5]. Microorganisms with sufficient oxygen conditions are able to degrade organic compounds (proteins, fats, carbohydrates, so forth) dissolved in domestic wastewater into simpler molecules. If the BOD price in water exceeds the specified threshold value, this could result in damage to the ecosystem in the waters. Waters that contain many plants will have a higher oxygen content because plants function to increase or increase oxygen levels. The primary source of oxygen is from plant synthesis through roots in the soil. Then oxygen through running water or rainwater causes oxygen to dissolve in water [19, 21].

Total Suspended Solid (TSS) is derived from natural sources, garbage, agricultural runoff water, fisheries, urban areas, and industry. In the Tembalang subdistrict, the total Suspended Solid (TSS) measurement result was $56.8 \mathrm{mg} / \mathrm{L}$, which is higher than Kramas Subdistrict $38.8 \mathrm{mg} / \mathrm{L}$ and Meteseh Sub-district $46.6 \mathrm{mg} / \mathrm{L}$. If wastewater that is channeled into drains/gutters contains high TSS levels, then the water becomes turbid and increases the temperature in the water. The result is reducing the oxygen dissolved in water and disrupting the life of aquatic habitats. High TSS levels result in the blocking of sunlight to the body of water so that the photosynthesis process of plants in these waters becomes disturbed [20].

\section{Conclusion}

The results of the IR spectrogram and zeolite $\mathrm{Si} / \mathrm{Al}$ ratio show that zeolite, which is activated by acid, shows a shift in wavenumber and different $\mathrm{Si} / \mathrm{Al}$ ratio. The $\mathrm{Si} / \mathrm{Al}$ ratio in natural zeolites was 4.57 and rose to 5.41 in $\mathrm{HCl}$ activated zeolites and increased again to 6.42 in $\mathrm{H}_{2} \mathrm{SO}_{4}$ activated zeolites. By using natural zeolite adsorbents, $\mathrm{HCl}$ activated zeolites and $\mathrm{H}_{2} \mathrm{SO}_{4}$ activated zeolites, a decrease in the value of water quality chemical parameters such as COD, $\mathrm{pH}, \mathrm{BOD}$, and TSS is as follows: Natural zeolite resulted in a decrease in COD of $21.8 \%$, pH of $11.5 \%$, BOD of $9.2 \%$ and TSS of $10.8 \%$. Whereas HCl activated zeolite reduced COD by $78.9 \%$, pH $16.2 \%$, BOD $11.8 \%$ and TSS $44.4 \%$. Moreover, $\mathrm{H}_{2} \mathrm{SO}_{4}$-activated zeolite succeeded in reducing COD by $85.5 \%$, pH $17.9 \%$, BOD $12.6 \%$, and TSS $49.7 \%$. From these results, it can be concluded that $\mathrm{H}_{2} \mathrm{SO}_{4}$-activated zeolite provides the best adsorption results.

\section{References}

[1] Daniel B. Botkin and Edward A. Keller, Environmental Science, Wiley, 2012

[2] Brewster Conant, Clare E. Robinson, Marc J. Hinton and Hazen A. J. Russell, A framework for conceptualizing groundwater-surface water interactions and identifying potential impacts on water quality, water quantity, and ecosystems, Journal of Hydrology, 574, (2019), 609-627 https://doi.org/10.1016/j.jhydrol.2019.04.050

[3] Sean Comber, Mike Gardner, Pernilla Sörme and Brian Ellor, The removal of pharmaceuticals during wastewater treatment: Can it be predicted accurately?, Science of The Total Environment, 676, (2019), 222-230 https://doi.org/10.1016/j.scitotenv.2019.04.113

[4] Shuaa Al-Maadheed, Ipek Goktepe, Aishah Binti A. Latiff and Basem Shomar, Antibiotics in hospital effluent and domestic wastewater treatment plants in Doha, Qatar, Journal of Water Process Engineering, 28, (2019), 60-68 https://doi.org/10.1016/j.jwpe.2019.01.005

[5] Nilasari Elok, M. Faizal and Suheryanto Suheryanto, Pengolahan Air Limbah Rumah Tangga dengan Menggunakan Proses Gabungan Saringan Bertingkat dan Bioremediasi Eceng Gondok (Eichornia Crassipes), (Studi Kasus di Perumahan Griya Mitra 2, Palembang), Jurnal Penelitian Sains, 18, 1, (2016), 8-13 https://doi.org/10.36706/jps.v18i1.34

[6] I Made Wahyu Wijaya and Eddy Setiadi Soedjono, Domestic wastewater in Indonesia: Challenge in the future related to nitrogen content, International Journal of GEOMATE, 15, 47, (2018), 32-41

[7] Haderiah Haderiah and Novi Utami Dewi, Meminimalisir Kadar Detergen Dengan Penambahan Koagulan dan Filtrasi Media Saring pada Limbah Kamar Mandi, HIGIENE: Jurnal Kesehatan Lingkungan, 1, 1, (2016), 33-41

[8] Kusdarto, Potensi Zeolit di Indonesia, Jurnal Zeolit Indonesia, 7, 2, (2008), 78-87

[9] Durali Danabas and Tulay Altun, Effects of zeolite (clinoptilolite) on some water and growth parameters of rainbow trout (Oncorhynchus mykiss Walbaum, 1792), Digest Journal of Nanomaterials and Biostructures, 6, 3, (2011), 1111-1116

[10] Zelal Polat, Integrated approach to whey utilization through natural zeolite adsorption/desorption and fermentation, Graduate School of Engineering and Sciences, İzmir Institute of Technology, İzmir

[11] L.R.G. de Araújo, C.L. Cavalcante Jr., K.M. Farias, I. Guedes, J.M. Sasaki, P.T.C. Freire, F.E.A. Melo and J. Mendes-Filho, Synthesis of cubic Y zeolite using a pulsed microwave heating system, Materials Research, 2, (1999), 105-109 https://dx.doi.org/10.1590/S1516-14391999000200011

[12] Halimaton Hamdan, Introduction to Zeolites: Synthesis, Characterization, and Modification, Universiti Teknologi Malaysia, Kualalumpur, 1992

[13] Xu Zhang, DaQing Tong, JingJing Zhao and XingYang $\mathrm{Li}$, Synthesis of NaX zeolite at room temperature and its characterization, Materials Letters, 104, (2013), 80-83 https://doi.org/10.1016/j.matlet.2013.03.131 
[14]Xu Zhang, Dingxing Tang, Min Zhang and Renchun Yang, Synthesis of NaX zeolite: Influence of crystallization time, temperature and batch molar ratio $\mathrm{SiO}_{2} / \mathrm{Al}_{2} \mathrm{O} 3$ on the particulate properties of zeolite crystals, Powder Technology, 235, (2013), 322328 https://doi.org/10.1016/j.powtec.2012.10.046

[15] Sugiarti Norvia, Suhartana Suhartana and Pardoyo Pardoyo, Dealuminasi Zeolit Alam Menggunakan Asam ( $\mathrm{HCl}$ dan $\mathrm{H}_{2} \mathrm{SO}_{4}$ ) untuk Katalis pada Proses Sintesis Biodiesel, Jurnal Kimia Sains dan Aplikasi, 19, 2, (2016), 72-76 https://doi.org/10.14710/jksa.19.2.72-76

[16] Nanik Sulistyowati, Sriyanti Sriyanti and Adi Darmawan, Effect of Acid on Natural Zeolite Dealumination on Indigo Carmine Adsorption Capability, Jurnal Kimia Sains dan Aplikasi, 21, 2, (2018), 102-106 https://doi.org/10.14710/jksa.21.2.102-106

[17] Sriatun Sriatun and Adi Darmawan, Dealuminasi Zeolit Alam Cipatujah Melalui Penambahan Asam dan Oksidator, Jurnal Kimia Sains dan Aplikasi, 8, 2, (2005), 55-60 https://doi.org/10.14710/jksa.8.2.5560

[18] Clair N. Sawyer and Perry L. McCarty, Chemistry for Environmental Engineering, McGraw-Hill, 1978

[19]Jingwei Li, Yifei Tong, Li Guan, Shaofeng Wu and Dongbo Li, A turbidity compensation method for COD measurements by UV-vis spectroscopy, Optik, 186, $\quad$ (2019), 129-136 https://doi.org/10.1016/j.ijleo.2019.04.096

[20]Sapto P Putro, Widowati Widowati and Suhartana Suhartana, Assessment Level of Severity of Environmental Disturbance Caused by Aquaculture Activities Using Abundance-Biomass Curves of Macrobenthic Assemblages, International Journal of Environmental Science and Development, 6, 3, (2015), 178-181

[21] Sapto Putro, Agung Sudaryono, Widowati Widowati and Suhartana Suhartana, Evaluation on the Application of Stratified Double Net Cages for Freshwater Fish Aquaculture: Macrobenthic Assemblages as Bioindicator, Aquacultura Indonesiana, 15, 1, (2015), 7-14 https://doi.org/10.21534/ai.v15i1.31 